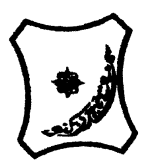

Bayero Journal of Pure and Applied Sciences, 12(1); 268 - 273

ISSN $2006-6996$

\title{
LOCAL PLANTS AND DIABETES MANAGEMENT; FOLKLORIC PRACTICES IN METROPOLITAN KANO, NIGERIA
}

\author{
Sani S. B., ${ }^{1 *}$ Aliyu, B.S., ${ }^{2}$ Musa Haruna ${ }^{1}$, Sani Muhammad Yahya ${ }^{1}$, Mardiyya Auwal \\ Yakasai $^{1}$, Ya'u Sabo Ajingi ${ }^{1}$, Ladan Wada Hayatu ${ }^{1}$ and Hamisu Abba ${ }^{1}$ \\ Department of Biology, Kano University of Science and Technology Wudil, P.M.B. 3244 Kano State, \\ Nigeria ${ }^{1}$. \\ Department of Plant Biology, Bayero University Kano, P.M.B 3011 Kano State, Nigeria². \\ *Corresponding author: sakinasanibuhari@yahoo.com
}

\begin{abstract}
An ethno botanical survey was carried out in Kano metropolis to investigate medicinal plants used locally for the treatment of diabetes in the area. The respondents for the study included herbalists and herb sellers. Oral interview was used to obtain information from the respondents using their local language and the information was recorded in a semi structured questionnaire. A total of 39 medicinal plant species belonging to 21 families were recorded in the study area. Family Fabaceae had the highest number of plant species and most of the plants were sourced from the wild. The plants were prepared mostly in their dried form and decoction was the most commonly used method of preparation. Moreover, combination of different plants or their parts in the preparation of the recipes for the treatment of diabetes was common among the respondents. Annisopus manii, Laptadenia hastata and Moringa oleifera were the most cited medicinal plants in the preparation of recipes for the treatment of diabetes mellitus in the study area
\end{abstract}

Keywords: Diabetes management, folkloric, medicinal, plants

\section{INTRODUCTION}

Diabetes is a metabolic disorder which results due to deficiency in insulin and its metabolism (Sani and Nair, 2017). The prevalence of diabetes mellitus (DM) is increasing worldwide and it is projected that by the year 2030 over 500 millions adult will be affected by the disease (Sabir et al., 2019). Diabetes is an expensive disease due to costs result from treating the disease with medication or insuling injection and costs result from treating complications of the disease (Oguejiofor et al., 2014). For many, costs of these medications especially insulin consume monthly minimum wages, in a country where National Health Insurance Scheme (NHIS) coverage is $<5 \%$ and most of the coverage still go to the privileged working class (Oguejiofor et al., 2014). Therefore, there is need for search of an alternative including herbal medicine for the treatment of the disease.

Herbal medicine is an important and significant part of traditional medicine which involves the use of plants or their parts (leaves, roots, flowers, stem, seeds etc) in the form of crude drugs such as powder, decoction, tincture, poultice and other herbal preparations for the treatment of diseases. Herbal medicine is still the mainstay of about $75-80 \%$ of the world population mainly in developing countries for primary health care (Tilburt and Kaptchuk, 2003). This is primarily because of their availability, accessibility and affordability as well as general belief that herbal medicine are without any side effects and are more effective than modern medicine. The growing testimonies of increasing effectiveness of herbal medicine coupled with much lower occurrence of side effects made herbal medicine a ready alternative to modern medicine. Hence it is important to explore herbal remedies for the treatment of diabetes mellitus in Kano northern Nigeria.

\section{MATERIALS AND METHODS STUDY AREA}

Kano state is located in the North-west geopolitical zone of Nigeria located on $12^{\circ} \mathrm{N}$ and $8^{\circ} 30^{\prime} \mathrm{E}$. It has a total area of $20,131 \mathrm{~km} 2$ (Ali et $a l ., 2017)$. It is one of the largest states in Nigeria in terms of population of about $9,383,682$ in the 2006 census. The state has been a commercial and agricultural center. The state is endowed with biodiversity of medicinal plants which have long being used in the African traditional system of medicine for the treatment of various illnesses. 
Special Conference Edition, November, 2019 DATA COLLECTION

The study was conducted in Kano metropolis from September to November, 2017. The target groups for the ethno-botanical survey were the herbalists and herb sellers. Oral interview was used to obtained information from the target groups and the data was recorded in a semistructured questionnaire (Appendix 1). The collected data was analyzed using descriptive statistics such as frequency and percentage.

\section{RESULTS AND DISCUSSION Medicinal plants reported}

A total of 100 respondents were interviewed in the study. The respondents reported the use of thirty nine (39) medicinal plants in the treatment of diabetes mellitus in the study area.. These plants belong to twenty one (21) families. Family Fabaceae had highest number of medicinal plants for the treatment of the disease followed by Malvaceae, Euphorbiaceae , Capparaceae and Asclepiadaceae. (Table1). It was observed in the study that leaves and Stem were the most reported anti diabetic plant parts in the study area (Figure 1). This result is in line with the study of Negbenebor et al. (2017). In addition trees were the major source of plant parts, followed by shrubs, herbs and grass. Majority of the plants were sourced from the wild only $5 \%$ are cultivated. This findings is also supported by the study of Ali et al.(2017) that majority of medicinal plants used in Kano metropolis are sourced from the wild.

It was observed in this study that Laptadenia hastate, Anisopus manii and Moringa oleifera were the most mentioned anti-diabetic plants by the respondents in the study area (Table 2). A literature search on anti diabetic activity of the most mentioned plants in this study was carried out. According to literature search, all the three plants possessed anti-diabetic activity when tested both in vitro and in vivo (Bello et al., 2011; Ukwuwani and Igbokwu, 2015; Khan et al., 2017; Zaruwa et al., 2018 )

Recipes, method of preparation, administration and the dosage form.

Formulation for the treatment of diabetes in the study area by the respondents were made mostly from combination of two or more plant species, while some were made from a single plant part (Table2). The respondents claimed that if a disease is associated with complications, combining different plants or their parts is vital to eradicate the associated complications. This is also supported by the report of Abubakar et al., (2017) that polyherbal therapies have synergistic and antagonistic pharmacological agents within themselves that work together in a dynamic way to produce therapeutic efficacy with minimal side effect. Decoction and oral administration were the most prepared method of preparation and administration. It was observed that majority of the plants are prepared in their dried form. This is in line with the study of Salihu et al. (2015).

In addition, the dosage form of the recipes is mostly 1 cup once, twice or thrice daily for a period of 1 week to two weeks depending on the severity of the disease. One to two teaspoons of dried powdered recipes could also be dissolved in liquid food, such as kunu (a pap) or yoghurt and water once or twice daily (Table 2). 
Special Conference Edition, November, 2019

Table 1: shows the distribution of medicinal plants used for the treatment of diabetes in Kano metropolis

\begin{tabular}{|c|c|c|c|c|c|}
\hline Family & Botanical name & Local name & Parts used & Habit & Form \\
\hline Amaranthaceae & Amaranthus hybridus & Alaiyahu & Leaves & $\mathrm{H}$ & C \\
\hline \multirow[t]{2}{*}{ Anacardiacea } & Lannea microcarpa & Faru & Leaves & $\mathrm{T}$ & W or C \\
\hline & Mangifera indica & Mangoro & Leaves & $\mathrm{T}$ & WorC \\
\hline Annonaceae & Annona senegalensis & Gwandar jeji & Root & $\mathrm{S}$ & W \\
\hline \multirow{2}{*}{ Arecaceae } & Hyphaene thebaica & Goruba & Fruit & $\mathrm{T}$ & W \\
\hline & Leptadenia hastata & Yadiya & $\begin{array}{l}\text { Leaves, stem } \\
\text { bark, root }\end{array}$ & $\mathrm{H}$ & W \\
\hline Asclepiadaceae & Anisopus mannii & Kashe zaki & $\begin{array}{l}\text { Leaves, stem } \\
\text { bark, root }\end{array}$ & $\mathrm{H}$ & W \\
\hline Asteraceae & Vernonia Kotschyana & Domashi & $\begin{array}{l}\text { Stem bark, } \\
\text { root }\end{array}$ & $\mathrm{S}$ & W \\
\hline Bignoniaceae & $\begin{array}{l}\text { Stereospermum } \\
\text { kunthianum }\end{array}$ & Sansami & Stem bark & $\mathrm{T}$ & W \\
\hline \multirow[t]{2}{*}{ Capparaceae } & Cadaba farinosa & Bagayi & Leaves & $\mathrm{S}$ & W \\
\hline & Boscia angustifolia & Farin moru & Stem bark & $\mathrm{T}$ & W \\
\hline Combretaceae & Combretum altum & Geza & Leaves, root & $\mathrm{S}$ & W \\
\hline Compositae & Vernonia amygdalina & Shuwaka & Leaves & $\mathrm{S}$ & C \\
\hline \multirow[t]{2}{*}{ Costaceae } & Cadalvena dalzielii & Takalmin zomo & Leaves & & \\
\hline & Jatropha curcas & Cini da zugu & Stem bark & $\mathrm{S}$ & W \\
\hline \multirow[t]{4}{*}{ Euphorbiaceae } & $\begin{array}{l}\text { Chrozophora } \\
\text { senegalensis }\end{array}$ & $\begin{array}{c}\text { Damagi/Baurenki } \\
\text { yashi }\end{array}$ & Stem bark & $\mathrm{S}$ & W \\
\hline & Paradaniellia oliveri & Maje & Stem bark & $\mathrm{T}$ & W \\
\hline & Isoberlinia doka & Doka & Stem bark & $\mathrm{T}$ & W \\
\hline & Dichrostachys nutans & Dundu & Leaves & $\mathrm{S}$ & W \\
\hline \multirow[t]{6}{*}{ Fabaceae } & Afzelia Africana & Kawo & Stem bark & $\mathrm{T}$ & W \\
\hline & Detarium microcarpum & Taura & Stem bark & $\mathrm{T}$ & W \\
\hline & $\begin{array}{l}\text { Trigonella foenum- } \\
\text { graecum } L\end{array}$ & Hulba & Seed & $\mathrm{H}$ & C \\
\hline & Entada sudanica & Tawatsa & Stem bark & $\mathrm{T}$ & W \\
\hline & Tephrosia elongata & Shege ka tsinka & leaves & G & $\mathrm{W}$ or $\mathrm{C}$ \\
\hline & Senna occidentalis & Rai dore & leaves & $\mathrm{S}$ & WorC \\
\hline \multirow[t]{4}{*}{ Fabaceae } & Cassia tora & Tafasa & leaves & S & W \\
\hline & Pterocarpus erinaceus & Modobiya & Root & $\mathrm{T}$ & W \\
\hline & Erythrina senegalensis & Minjirya & $\begin{array}{l}\text { Leaves, stem } \\
\text { bark }\end{array}$ & $\mathrm{T}$ & W \\
\hline & Tamarindus indica & Tsamiya & Fruits & $\mathrm{T}$ & W \\
\hline \multirow[t]{2}{*}{ Lamiaceae } & Vitex cienkowskii & Dinya & Stem & $\mathrm{T}$ & WorC \\
\hline & Sterculia setigera & Kukuki & Stem bark & $\mathrm{T}$ & W \\
\hline \multirow[t]{2}{*}{ Malvaceae } & Hibiscus sabdariffa & Soborodo & Flower & $\mathrm{S}$ & C \\
\hline & Adansonia digitata & Kuka & Fruit & $\mathrm{T}$ & WorC \\
\hline Meliaceae & Khaya senegalensis & Madaci & Stem bark & $\mathrm{T}$ & W \\
\hline Moraceae & Ficus thonningii & Chediya & Stem bark & $\mathrm{T}$ & W \\
\hline Moringaceae & Moringa oleifera & Zogale & Leaves & $\mathrm{T}$ & WorC \\
\hline Myrtaceae & Syzygium aromatica & Kanumfari & Fruit & $\mathrm{H}$ & C \\
\hline Olacaceae & Ximenia americana & Tsada & Leaves & $\mathrm{T}$ & W \\
\hline Poacea & Echinochloa stagnina & Buruku & Stem bark & G & W \\
\hline
\end{tabular}

Habit; S- shrub, T- tree, P-palm, G-grass, Form; W- wild, C- cultivated. 
Special Conference Edition, November, 2019

Table 2: Formulation, method of preparation, method of administration and dosage form of plants locally used for the treatment of diabetes

\begin{tabular}{|c|c|c|c|}
\hline Formulation & $\begin{array}{l}\text { How plant } \\
\text { part is used }\end{array}$ & $\begin{array}{l}\text { Method of } \\
\text { Preparation }\end{array}$ & Administration and dosage \\
\hline Anisopus mani(l) & Dried & Powdered & $\begin{array}{l}1 \text { teaspoonful in kunu/yogurt } \\
\text { twice daily for two weeks }\end{array}$ \\
\hline $\begin{array}{l}\text { Anisopus mani }(\mathrm{I})+\text { Leptadenia } \\
\text { hastata }(\mathrm{I})+\text { Isoberlinia doka }(\mathrm{sb})\end{array}$ & Dried & Decoction & $\begin{array}{l}\text { Taken orally } 1 / 2 \text { cup twice } \\
\text { daily }\end{array}$ \\
\hline $\begin{array}{l}\text { Anisopus manii (sb)+ Leptadenia } \\
\text { hastata(sb)+red potash }\end{array}$ & Dried & Infusion/maceration & Taken orally twice daily \\
\hline $\begin{array}{l}\text { Anisopus manii }(r)+\text { Leptadenia hastata } \\
(\mathrm{I})+\text { Moringa oleifera }(\mathrm{I})\end{array}$ & Dried & Decoction & Taken orally1 cup daily \\
\hline $\begin{array}{l}\text { Anisopus manii } \\
\text { Kotchyana(I) }\end{array}$ & Dried & Decoction & Taken orally 1 cup daily \\
\hline $\begin{array}{l}\text { Anisopus manii }+ \text { Annona } \\
\text { senegalensis }(r)+\text { Moringa oleifera }(\mathrm{I})\end{array}$ & Dried & Decoction & Taken orally 1 cup daily \\
\hline $\begin{array}{l}\text { Anisopus manii }(r)+\text { Leptadenia hastata } \\
(r)+\text { Combretum altum }(r)+\text { Lemon }\end{array}$ & Dried & Decoction & $\begin{array}{l}\text { 1cup is taken twice daily for } \\
\text { two weeks }\end{array}$ \\
\hline Anisopus manii (I)+ Cadaba farinosa(I) & Dried & Powdered & $\begin{array}{l}1 \text { teaspoonful is taken in } \\
\text { yoghurt daily for two weeks }\end{array}$ \\
\hline 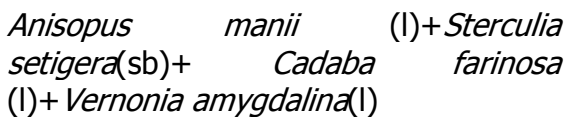 & Dried & Decoction & $\begin{array}{l}\text { Taken orally } 1 \text { cup twice daily } \\
\text { for } 3 \text { weeks }\end{array}$ \\
\hline Hyphaene thebaica(fr) & Dried & Decoction & $\begin{array}{l}\text { Taken orally I cup for two } \\
\text { weeks }\end{array}$ \\
\hline $\begin{array}{l}\text { Anisopus manii } \quad(\mathrm{sb})+\text { Vitex } \\
\text { cienkowskii(s)+ Hibiscus sabdariffa(fr) }\end{array}$ & Dried & Decoction & $\begin{array}{l}\text { 1/2cup twice daily for two } \\
\text { weeks }\end{array}$ \\
\hline Leptadenia hastata (I)+red potash & Dried & Decoction & 1 cup twice daily \\
\hline $\begin{array}{l}\text { Leptadenia hastata }(\mathrm{I})+\text { Cadaba } \\
\text { farinosa (I) }\end{array}$ & Dried & Decoction & $\begin{array}{l}\text { Taken orally } 1 \text { cup twice daily } \\
\text { for two weeks }\end{array}$ \\
\hline $\begin{array}{l}\text { Leptadenia hastata } \\
\text { oleifera(I) }\end{array}$ & Fresh & Decoction & 1 cup daily \\
\hline $\begin{array}{l}\text { Leptadenia hastata (I)+Stereospermum } \\
\text { kunthinum(sb) }\end{array}$ & Dried & Powdered & 1 teaspoon is taken in water \\
\hline Khaya senegalensis(sb) & Dried & Powdered & $\begin{array}{l}1 \text { scoop of groundnut shell in } 1 \\
\text { cup of water }\end{array}$ \\
\hline Cadaba farinosa (I) & Dried & Powdered & $\begin{array}{l}1 \text { teaspoon is taken in yoghurt } \\
\text { twice daily }\end{array}$ \\
\hline $\begin{array}{l}\text { Annona senegalensis(r)+Paradaniellia } \\
\text { oliveri(sb)+Detarium microcarpum(sb) }\end{array}$ & Dried & Decoction & 1 cup twice daily for two weeks \\
\hline $\begin{array}{l}\text { Vernonia amygdalina(I)+Amaranthus } \\
\text { hybridus(I) }\end{array}$ & Fresh & Crush & $\begin{array}{l}1 / 2 \text { teaspoon of the extract is } \\
\text { taken for } 2 \text { weeks }\end{array}$ \\
\hline Echinochloa stagnina+red potash & Dried & Powdered & In water 1 cup daily \\
\hline $\begin{array}{l}\text { Vernonia amygdalina(l)+Trigonella } \\
\text { foenum-(sd) }\end{array}$ & Dried & Powdered & $\begin{array}{l}1 \text { teaspoonful is taken in water } \\
\text { in an empty stomach }\end{array}$ \\
\hline Senna occidentalis $(I+r)+$ red potash & Dried & Decoction & 1 cup daily for two weeks \\
\hline Afzelia africana(sb) & Dried & Infusion & $\begin{array}{l}1 \text { cup daily in an empty } \\
\text { stomach }\end{array}$ \\
\hline $\begin{array}{l}\text { Chrozophora senegalensis }(\mathrm{sb}+\mathrm{r})+\mathrm{red} \\
\text { potash }\end{array}$ & Dried & Infusion & 1 cup daily \\
\hline $\begin{array}{l}\text { Lannea } \quad \text { microcarpa(I)+Isoberlinia } \\
\text { doka(sb) }\end{array}$ & Dried & Powdered & $\begin{array}{l}1 \text { teaspoon is taken in yogurt } \\
\text { daily for } 2 \text { weeks }\end{array}$ \\
\hline Ficus thonningii(sb)+red potash & Dried & Decoction & 1 cup thrice daily \\
\hline Moringa oleifera(I) +Mangifera indica(I) & Fresh & Decoction & 1 cup daily \\
\hline Adasonia digitata (fr) & Dried & Maceration & 1 cup thrice daily \\
\hline Cassia tora(I) & Dried & Powdered & To be taken with yoghurt \\
\hline $\begin{array}{l}\text { Dichrostachys nutan } \\
\text { americana+red potash }\end{array}$ & Dreied & Decoction & 1 cup daily \\
\hline Cadaba farinosa + Tamarindus indica & Fresh & Decoction & I cup daily \\
\hline Erythrina senegalensis & Dried & Boil & Orally 1 cup twice daily \\
\hline
\end{tabular}

I-leaf, sb-stem bark, sd-seed, r-root, fr-fruit 


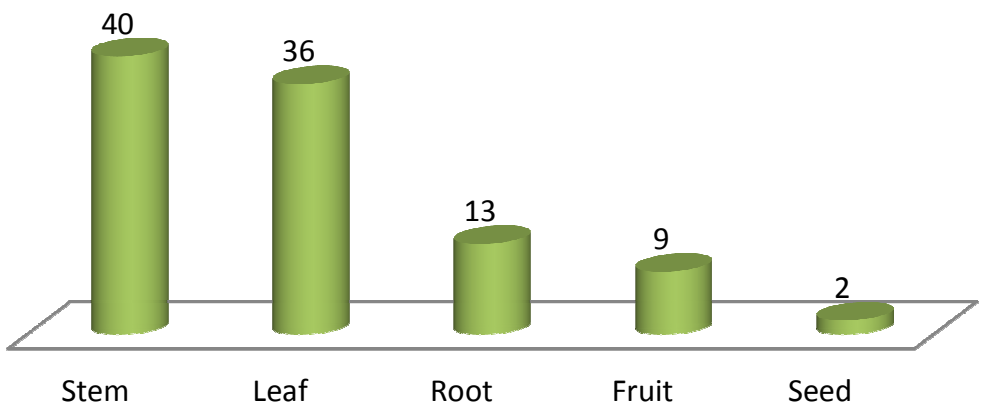

Figure1: percentage distribution of plant parts used

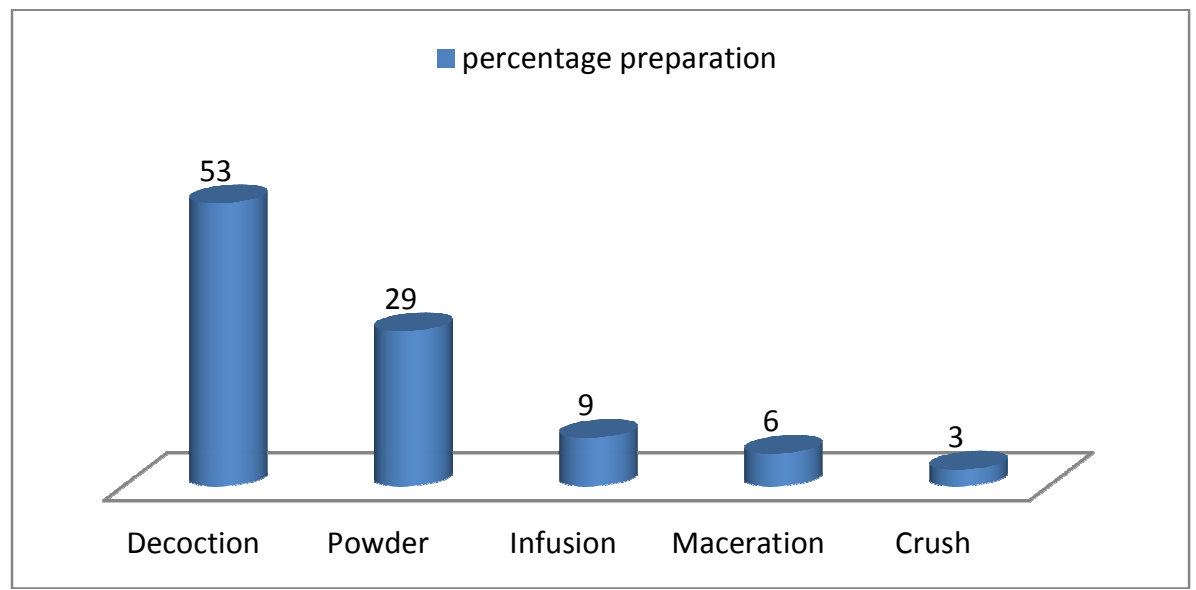

Figure 2: Percentage distribution of method of preparation

\section{CONCLUSION}

A total of 39 medicinal plants were recorded in this study for the treatment of diabetes mellitus in the study area. Annisopus manii, Laptadenia hastata and Moringa oleifera were the most cited medicinal plants in the preparation of recipes for the treatment of diabetes mellitus in

\section{REFERENCES}

Abubakar, U.S., Yusuf, K.M., Abdu, G.T., Saidu, S.R., Jamila, G.A. and Fatima, A. (2017). Ethnorpharmacological survey of medicinal plants used for management of pediatric ailments in Kano state, Nigeria. Research Journal of Pharmacognosy, 4(3):29-39

Ali, M., Diso, S.U., Minjibir, A.A., Sani, J.A., Nas, F..S. and Yahya, A. (2017). Assessment of medicinal plants used in treatment of various ailment in Kano city Nigeria. Asian Journal of Bioresources technology, 2(4):1-11

Bello, A., Aliero, A.A., Saidu, Y. and Muhammad, S. (2011). Hypoglycaemic and Hypolipidaemic effects of Laptadenia hastata Pers.) Decne in Alloxan Induced the study area. Stem and leaves were the most used plant parts and decoction was the most common preparation method for the treatment of the disease. However, further studies need to be conducted to prove the efficacy of the plants both in vitro and in vivo.

Diabetic Rats. Nigerian Journal of Basic and Applied Sciences, 19(2):187-192

Khan, W., Parveen R., Chester K., Parveen, S., and Ahmad, S.(2017). Hypoglycemic Potential of Aqueous extract of Moringa oleifera Leaf and in vivo GC-MS Metabolomics. Frontiers in pharmacology, 8(577):1-16

Negbenebor, H.E., Shehu, K., Mukhtar, M.F., Oiza, A.Z., Nura, S. and Fagwalawa, L.D. (2017). Ethno Botanical Survey of Medicinal Plants Used by Hausa People in the Management of Diabetes Mellitus in Kano Metropolis, Northern Nigeria. European Journal of Medicinal Plants, $18(2): 1-10$

Oguejiofor, O., Odenigbo, C. and Onwukwe C. (2014). Diabetes in Nigeria: Impact, 
Special Conference Edition, November, 2019

Challenges, Future Direction. Endocrinology and Metabolic Syndrome, 3(2):1-9

Sabir, A.A., Balarabe, S., Atta, S.A., Simeon, I., Sada, K.B., Jimoh, A.O. and Sandra, O.I. (2019).Prevalence of Diabetes mellitus and its risk factors among the suburban population of Northwest Nigeria. Sahel Medical Journal, 20:168-172

Salihu, T.S., Bello, L., Hassan, S.W. and Ali, S. (2015). An ethnobotanical survey of antidiabetic plants used by Hausa-Fulani tribes in Sokoto, Northwest Nigeria. Journal of Ethnopharmacology, 172:9199

Sani, S.B. and Nair,S.S. (2017). Studies on in vitro evaluation and antidiabetic

potentials of watermelon and pomegranates peels. Bayero Journal of Pure and Applied Sciences, 10(1):32-35

Tilburt, T.C. and Kaptchuk, T.J. (2003). Herbal medicine research and global health:an ethical analysis. Buletin of the world Health Organization, 86(8):594-599..

Ukwuani, A.N. and Igbokwu, M.O (2015). In vitro antidiabetic effect of Leptadenia hastata leaves. Biosciences Research in Today's World, 1:40-46

Zaruwa, M.Z, Manosroi, J., Akihisa, T. and Manosroi, A. (2018). Manosrin a new hypoglycaemic compound from Anisopus mannii N.E.Br. international Journal of Advanced Research and Publications, 2(8):72-78

1. Date

BAYERO UNIVERSITY KANO

DEPARTMENT OF PLANT BIOLOGY

MEDICINAL PLANTS FOR DIABETESE MANAGEMENT

RESEARCH QUESTIONNAIRE

2. Name.

3. Address

4. Gender.....

5. Occupation

6. Formal training in herbal/plant medicine:10yrs [ ] 10-20yrs [ ] 21-30yrs [ ] 31yrs \& above

7. Do you have any knowledge of diabetes? Yes [ ] No [ ]

8. Diagnostic measure: Observation of the patient [ ] Patient feedback [ ]

9. Are there herbal remedies for diabetes? Yes [ ] NO[ ]

10. Plant(s) used?

11. Plant part(s) used (?)in medicine: Leaf [ ] Stem bark [ ] Root [ ] Flower [ ] Fruit[ ] Seed [ ]

12. How plant part(s) is used? Fresh [ ] Dried [ ]

13. Is this part(s) used in combination with other ingredient(s)?

Yes.

14. Method of preparation for used

No [ ]

15. Method of administration

16. Dosage form.

17. Any other information 